\title{
Analysis of the distribution of temperature and humidity in different variants of external walls made of hemp-lime composite
}

\author{
Anna Alberska, Przemyslaw Brzyski \\ Department of Construction, Faculty of Civil Engineering and Architecture, \\ Lublin University of Technology, e-mail: p.brzyski@pollub.pl, anna.alberska@pollub.edu.pl
}

\begin{abstract}
Proper design of the building component, which not only meets the legal requirements, but also provides comfort of using of buildings, requires knowledge of the materials and solutions. Since moisture is one of the main factors that can affect the building structure destruction, it is particularly important to be aware of hygrothermal properties of components. And this is the focus of the study. In this paper several variants of external walls were analysed, according to the requirements in terms of: heat transfer coefficient $U$, the risk of surface and interstitial condensation. Partitions were designed with composite based on shives from industrial hemp and lime binder, which is not yet widely used in Poland. The purpose of the analysis of this material was to prove the validity of using the natural materials in residential buildings.
\end{abstract}

Keywords: condensation, thermal conductivity, moisture, industrial hemp, lime.

\section{Introduction}

The most important task given architecture is providing safety and comfort of use of building. It has particular meaning in case of objects, where people spent most of the day, work or live. This kind of structures has to protect from weather conditions (rain, snow, wind, temperature) as well as provide adequate microclimate in their interiors. Manufacturers of building materials take it into consideration and race in search of solutions, which ensure increased tightness and thermal insulation of building partitions. At the same time, they notice a need to reduce gas and dust emissions and energy consumption, what clashes with an idea of creating new solutions using complicated technological processes or plastics, or both. Therefore it should be considered to take a sort of step back and test whether natural, renewable materials can be used in construction and successfully meet the criteria of safety and comfort of use buildings. The one of this kind of materials is described in the paper, hemp-lime composite, which is acclaimed in countries as France, Belgium or Great Britain, but is still not popular in Poland.

\section{Hemp-lime composite}

Hemp have been being used in construction for at least several centuries. The one of examples is The Nakamura Family Residence, which was built in 1698 in Japanese village Miasa [1].The building's thatched roof is made of hemp stalks joined by hemp ropes [2]. Nevertheless, the history of the use of composite began in France in the 80's of the $19^{\text {th }}$ century through Charles Rasetti, who has been using hemp shives to repairbuilt in the midsixteenth century in the Champagne house known as The House of the Turk or La Maison 
de la Turque consisted of oak frame filled with lime, straw and rubble[3]. Since that time new material has been gaining in popularity. In France it has given the trade name Isochanvre [3], but now is better known under English-speaking names such as hemp lime, hemcrete or hempcrete [4].

Composite (Fig. 1) consist of hemp shives mixed with lime binder and water in proportion matched depending on density, indicated properties, method and setting material. Hemp straw used to manufacturing of shives has to meet a number of requirements. It must be dry and clean, do not contain dust or any foreign objects such as other plants or seeds, and do not bear traces of biological corrosion. Production of the composite structure with good thermal insulation is provided by an appropriate fraction of the shives (Fig. 2). The literature [4] gives that should be equal pieces with the length of about $25 \mathrm{~mm}$ or in the range $10 \div 25 \mathrm{~mm}$, but in case of sprayed mix, the fractions above $20 \mathrm{~mm}$ may cause a clogging of an unit [1].

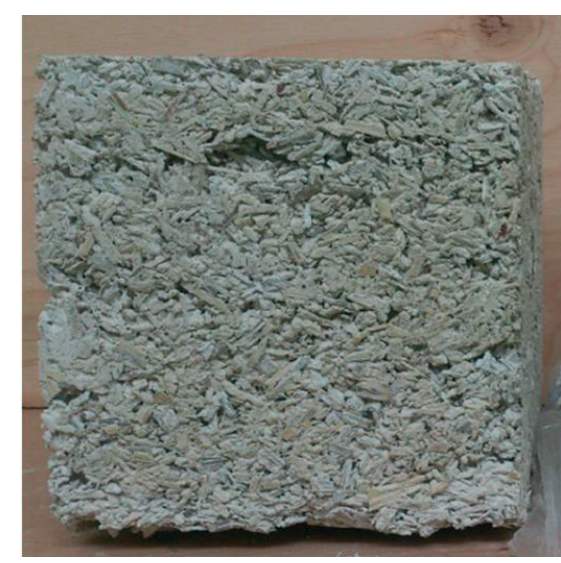

Fig.1. The sample of hemp-lime composite [authors' archive]

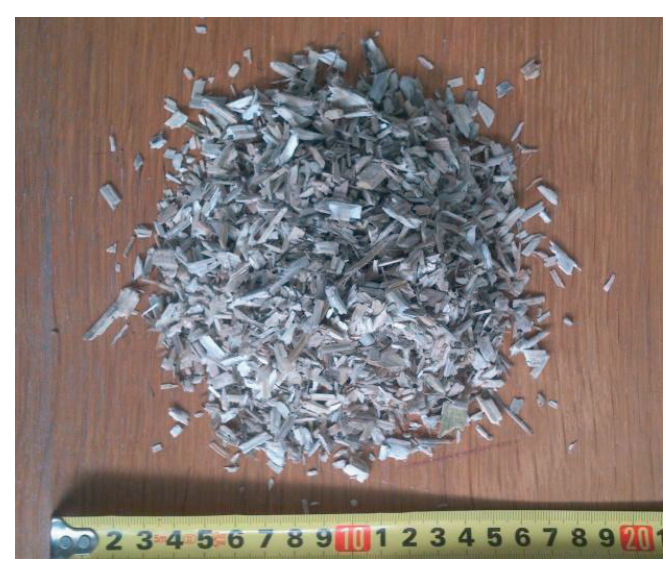

Fig.2. Hemp shives for building purposes [authors' archive]

The lime binder not only associate shives in a monolith, but also protect them from biological corrosion and increases the fire-resistance of the material. There are adhesives specially designed for the manufacture of composite (for example British Tradical HB or French Batichanvre [4]), which beside lime contains cement and pozzolan additives in proportions being a trade secret. Their task is to accelerate the hardening of the binder and reduce the time of drying.

In case of using ready-made half-products, manufacturer define their recommended metering. For example, to produce $1 \mathrm{~m}^{3}$ of hempcrete with ingredients manufactured by Lime Technology under the trade Tradical Hemcrete, are needed: $220 \mathrm{~kg}$ of lime and 110 $\mathrm{kg}$ of shives [4]. If widely available components are used, right proportions can be found in literature. Exemplary recipes are shown in Tab. 1.

Table 1. The volumetric dosing of components according to S. Allin [3]

\begin{tabular}{lllllll}
\hline Purpose & Shives & Water & Hydrated lime & Hydraulic lime & Cement & Fine sand \\
\hline Lightweight mix & 1801 & 401 & 201 & 101 & 51 & - \\
\hline Wall mix & 1801 & 601 & 301 & 151 & 51 & - \\
\hline Floor mix & 1801 & 601 & 301 & 201 & 101 & - \\
\hline Plaster mix & 1801 & 801 & 901 & 301 & 151 & 201 \\
\hline
\end{tabular}




\section{Hygrothermal properties of the material}

The composite has a good vapor permeability, which prevents condensation and fungi attacks. Studies, which results were presented by A. Evrard at a conference in 2006 [5] proved this feature. For samples prepared and thickened similar to the conditions of the construction, the diffusion resistance coefficient $\mu$ was 5 . At the same time the material retains a high air-tightness. Tests conducted at the English office headquarters Lime Technology gave the score $3 \mathrm{~m}^{3} /\left(\mathrm{m}^{2} \mathrm{~h}\right)$ [4], which is more than three times the lower limit of the air-tightness of new housing, service buildings and public buildings in the United Kingdom $-10 \mathrm{~m}^{3} /\left(\mathrm{m}^{2} \mathrm{~h}\right)$ [6]. In addition, further research showed that most of the leaks came from the old windows and ventilation pipes.

The lowest of the common coefficients of thermal conductivity $\lambda$ for the composite is $0.07 \mathrm{~W} /(\mathrm{m} \cdot \mathrm{K})$ and it is declared by Lime Technology for the mixture sprayed. In case of composite laid in shuttering this value may increase from 0.07 to $0.11 \mathrm{~W} /(\mathrm{m} \cdot \mathrm{K})$ [7]. However, analysis shows that is possible to achieve lower values. For example, research conducted by the University of Plymouth on the wall of a house in Suffolk gave result of the order of $0.08 \mathrm{~W} /(\mathrm{m} \cdot \mathrm{K})$ [4]. The coefficient $\lambda$, similar to diffusion resistance, increases with the density of the material.

The material has a large heat capacity, thanks to shives ability to absorb and release of energy associated with the change of concentration of water. These characteristics are not regulated by law or included in conventional methods of measuring thermal properties, but researches shown their impact on comfort of use. The study of the homes in Haverhill demonstrated that in buildings made of composite material, although they have a higher calculated heat transfer coefficient $U$ than buildings constructed in traditional technology, heating bills was lower, and tenants did not complain neither cold nor temperature fluctuations [4].

In addition, the thermal properties of the composite are similar to the properties of the wood, so thermal bridges, which can arise when filling of the frame is made with other, traditional insulating material (for example mineral wool), are levelled.

\section{The calculation of the heat transfer coefficient for external walls}

The heat transfer coefficient U was calculated in accordance with EN ISO 6946 [8] as the reciprocal of the arithmetic mean of the upper (1) and lower resistance limit (3).

$$
\frac{1}{R_{T}^{\prime}}=\frac{f_{a}}{R_{T a}}+\frac{f_{b}}{R_{T b}}+\ldots+\frac{f_{q}}{R_{T q}}
$$

where: $R_{T a}, R_{T b}, \ldots, R_{T q}$ - total thermal resistance from environment to environment for each divisional section calculated from the formula $(2)\left[\left(\mathrm{m}^{2} \cdot \mathrm{K}\right) / \mathrm{W}\right] ; f_{a}, f_{b}, \ldots, f_{q}$ - the relative surface area of each section

$$
R_{T j}=R_{s i}+R_{1 j}+R_{2 j}+\ldots+R_{n j}+R_{s e}
$$

where: $R_{s i}, R_{s e}$ - resistance of heat transfer on inside and outside surface $\left[\left(\mathrm{m}^{2} \cdot \mathrm{K}\right) / \mathrm{W}\right] ; R_{1 j}$, $R_{2 j}, \ldots, R_{n j}$ - computable thermal resistances of each layer for the separate section $\left[\left(\mathrm{m}^{2} \cdot \mathrm{K}\right) / \mathrm{W}\right]$ which are the quotient of the thickness of the layer $[\mathrm{m}]$ and computable thermal conductivity of material $\lambda[\mathrm{W} /(\mathrm{m} \cdot \mathrm{K})]$ 
The calculation of the lower resistance limit, given by the formula (3), must be preceded by a determination of equivalent thermal resistance of each o heterogeneous heat layer using the formula (4).

$$
\begin{aligned}
& R_{T}^{\prime \prime}=R_{s i}+R_{1}+R_{2}+\ldots+R_{n}+R_{s e} \\
& \frac{1}{R_{j}}=\frac{f_{a}}{R_{a j}}+\frac{f_{b}}{R_{b j}}+\ldots+\frac{f_{q}}{R_{q j}}
\end{aligned}
$$

The calculations was based on the values of the coefficients of thermal conductivity according to materials provided by Lime Technology [7], that is $0.07 \mathrm{~W} /(\mathrm{m} \cdot \mathrm{K})$ for sprayed mixtures and from 0.07 to $0.11 \mathrm{~W} /(\mathrm{m} \cdot \mathrm{K})$ for mixtures laid in the formwork. In all considered variants of the walls, timber frame is made with bars with the cross sections $50 \mathrm{~mm}$ by $150 \mathrm{~mm}$ and the axial spacing of $500 \mathrm{~mm}$.

The first analyzed variant was a wall thickness of $400 \mathrm{~mm}$ made of mixture laid in the traditional formwork and coated both sides with a layer of lime plaster with a thickness of $20 \mathrm{~mm}$, shown in Fig. 3.
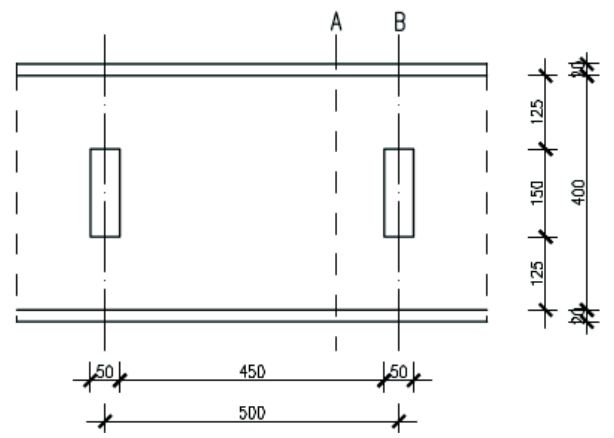

Fig. 3. The cross-section of a wall made of a mix formed in the formwork

The value of obtained heat transfer coefficient, depending on the values of the coefficient $\lambda$, was from 0.17 to $0.26 \mathrm{~W} /\left(\mathrm{m}^{2} \cdot \mathrm{K}\right)$. Additionally, size of the impact of a type of wall finish on the coefficient $U$ was tested. Lime plaster $(0.70 \mathrm{~W} /(\mathrm{m} \cdot \mathrm{K}))$ from the previous model was replaced with plaster based on hemp $(0.13 \mathrm{~W} /(\mathrm{m} \cdot \mathrm{K}))$. The exact results of the calculations are shown in the graph and the table presented in Fig. 4.

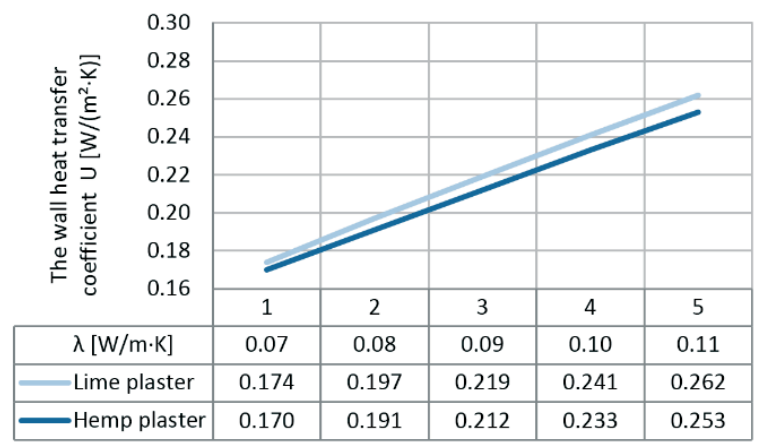

Fig. 4. Presentation of relations between heat transfer coefficient $U$ depending on obtained value of coefficient $\lambda$ of hempcrete and kind of finishing material 
Because profit from the application of the hemp plaster did not exceed $0.01 \mathrm{~W} /\left(\mathrm{m}^{2} \cdot \mathrm{K}\right)$, further calculations were carried out for lime plaster, which is more popular in Poland. Next analysis were related to the effect of wall thickness and density of the composite (which determines thermal conductivity of the material) on the heat transfer coefficient $U$. The calculation results are presented in Fig. 5.

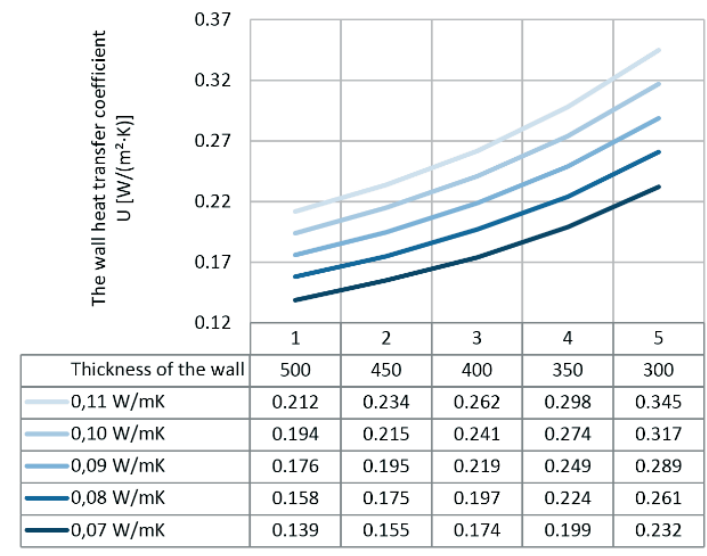

Fig. 5. Presentation of relations between heat transfer coefficient $U$ depending on value of coefficient $\lambda$ of hempcrete and thickness of the wall

The maximum values of heat transfer coefficients $U$ for all types of building partitions are included in the Regulation of the Minister of Infrastructure on the technical conditions for buildings and their location [9]. The values for external walls and the date of their entry into force are presented in Table. 2. Tab. 3. describes the compatibility of each model of the walls with the guidelines.

Table 2. The limiting values of heat transfer coefficient $U$ for external walls [9]

\begin{tabular}{llll}
\hline Effective date & 1.01 .2014 & 1.01 .2017 & 1.01 .2021 \\
\hline $\mathrm{U}\left[\mathrm{W} /\left(\mathrm{m}^{2} \cdot \mathrm{K}\right)\right]$ & 0.25 & 0.23 & 0.20 \\
\hline
\end{tabular}

Table 3. The requirements met by the wall models

\begin{tabular}{llllll}
\hline \multirow{2}{*}{ Thickness - $\mathrm{d}$} & \multicolumn{1}{l}{$\lambda$} & & \\
\cline { 2 - 5 } & $0.07 \mathrm{~W} /(\mathrm{m} \cdot \mathrm{K})$ & $0.08 \mathrm{~W} /(\mathrm{m} \cdot \mathrm{K})$ & $0.09 \mathrm{~W} /(\mathrm{m} \cdot \mathrm{K})$ & $0.10 \mathrm{~W} /(\mathrm{m} \cdot \mathrm{K})$ & $0.11 \mathrm{~W} /(\mathrm{m} \cdot \mathrm{K})$ \\
\hline $500 \mathrm{~mm}$ & 1.01 .2021 & & 1.01 .2017 & 1.01 .2014 \\
\hline $450 \mathrm{~mm}$ & 1.01 .2021 & & 1.01 .2014 & does not fulfill \\
\hline $400 \mathrm{~mm}$ & 1.01 .2021 & & 1.01 .2017 & does not fulfill & \\
\hline $350 \mathrm{~mm}$ & 1.01 .2021 & 1.01 .2017 & 1.01 .2014 & & \\
\hline $300 \mathrm{~mm}$ & 1.01 .2014 & & does not fulfill & & \\
\hline
\end{tabular}

As a second variant of the wall assumed a partition composed of a composite sprayed on the lose formwork made of $25 \mathrm{~mm}$ thick wood wool panels Heraklith $(\lambda=0.07 \mathrm{~W} / \mathrm{m} \cdot \mathrm{K})$ nailed to a wooden frame and the insulating layer of wool hemp STEICOcanaflex $(\lambda=0.04 \mathrm{~W} / \mathrm{m} \cdot \mathrm{K})$. Several cases of walls with variable thickness of the composite and wool, were analyzed. The variant with a $25 \mathrm{~cm}$ thick layer of composite and $5 \mathrm{~cm}$ hemp wool is shown in Fig. 6. 


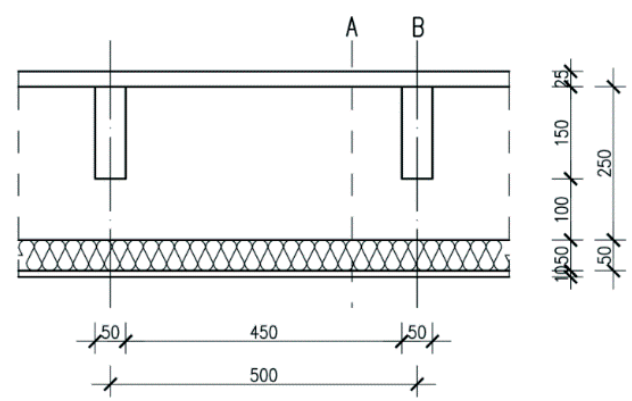

Fig. 6. The cross-section of a wall made of a mix sprayed on the formwork

The results of calculation of heat transfer coefficient $U$ are shown in Fig. 7.

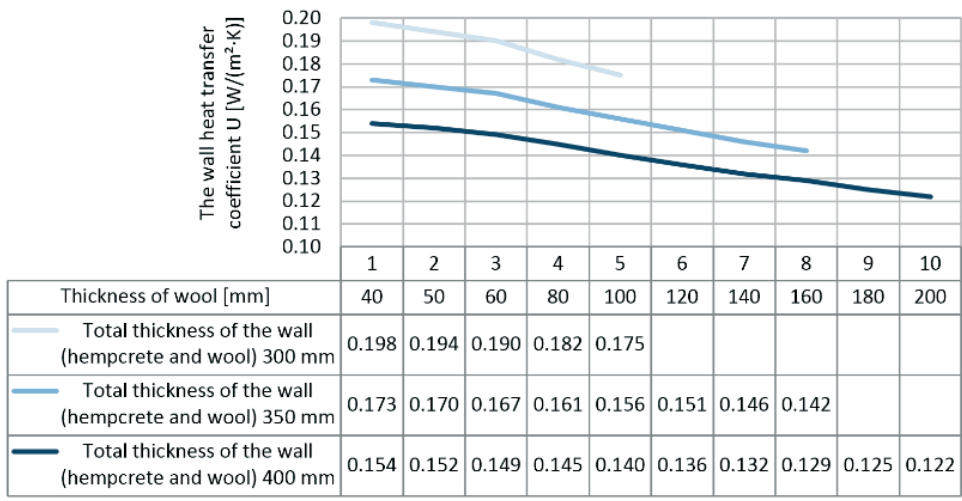

Fig. 7. Presentation of relations between heat transfer coefficient $U$ depending on total thickness of the wall (hempcrete and wool) and thickness of hemp wool

In the analysis of various cases within the second variant of wall achieved lower values of heat transfer coefficient $U$, thus checked models not only meet the criteria contained in the technical conditions [9], but also the requirements of The National Fund for Environmental Protection and Water Management (NFEP\&WM) [10] made for partitions of energy efficient and passive buildings applying for a grant. These requirements are presented in the Tab. 4. Tab. 5. Shows a position of analyzed models and criteria, which they meet.

Table 4. Values of the heat transfer coefficient $U$ for external walls according to criteria of NFEP\&WM's program [10]

\begin{tabular}{llll}
\hline Standard & & $\mathrm{NF} 15$ & $\mathrm{NF} 40$ \\
\hline \multirow{2}{*}{$\mathrm{U}\left[\mathrm{W} /\left(\mathrm{m}^{2} \cdot \mathrm{K}\right)\right]$} & minimal & 0.12 & 0.20 \\
\cline { 2 - 4 } & recommended & 0.10 & 0.15 \\
\hline
\end{tabular}

Table 5. The requirements met by the wall models

\begin{tabular}{|c|c|c|c|c|c|c|c|c|c|c|}
\hline \multirow{2}{*}{$\begin{array}{l}\text { the total thickness of the } \\
\text { composite and wool }[\mathrm{mm}]\end{array}$} & \multicolumn{10}{|c|}{ the thickness of the used hemp wool $[\mathrm{mm}]$} \\
\hline & 40 & 50 & 60 & 80 & 100 & 120 & 140 & 160 & 180 & 200 \\
\hline 400 & \multicolumn{10}{|c|}{ NF 40} \\
\hline 350 & \multicolumn{5}{|c|}{1.01 .2021} & \multicolumn{3}{|c|}{ NF 40} & - & - \\
\hline 300 & \multicolumn{5}{|c|}{1.01 .2021} & - & - & - & - & - \\
\hline
\end{tabular}


On the basis of calculations of transfer coefficient $U$, for further analysis two examples (one from each variant) meeting the requirements which are to come into force on 1 January 2021 year were selected. The first variant was the $40 \mathrm{~cm}$ thick wall made of a composite laid in the formwork, assuming that coefficient of thermal conductivity $\lambda=0.08 \mathrm{~W} /(\mathrm{m} \cdot \mathrm{K})$ will be achieved. A second variant was the wall consist of a $25 \mathrm{~cm}$ thick layer of composite, which is sprayed on lost formwork $(\lambda=0.07 \mathrm{~W} /(\mathrm{m} \cdot \mathrm{K}))$ and $5 \mathrm{~cm}$ thick layer of hemp wool.

\section{The determination of the risk of mold growth}

Heat and high humidity in the room can create conditions for the development of mold and mildew, which presence is dangerous for the health of users. Hence, during designing a building partitions is necessary to check the possibility of condensation of water vapour on the surface, which has an impact on the value of relative humidity which entails the risk of mold. This risk is determined in accordance with EN ISO 13778 [11] based on the value of the temperature factor $f_{R s i}$ on the inner side of the partition, which is calculated using the formula (5).

$$
f_{R s i}=\frac{\theta_{s i, \min }-\theta_{e}}{\theta_{i}-\theta_{e}}
$$

where: $\theta_{s i \text { min }}$ - inner surface temperature $\left[{ }^{\circ} \mathrm{C}\right] ; \theta_{i}$ - internal air temperature $\left[{ }^{\circ} \mathrm{C}\right] ; \theta_{e}-$ outside air temperature $\left[{ }^{\circ} \mathrm{C}\right]$

A factor is calculated for each month on the basis of monthly average temperature $\theta_{e}$ and humidity $\varphi_{e}$ (depending on the location of the building), which serve to determine the value: saturated vapour pressure $p_{s a t}(6,7)$ and actual water vapour pressure $p_{e}(8)$. It is also necessary to: determine an excess of atmospheric pressure $\Delta p$, calculate the monthly mean value of water vapour pressure on the inner surface $p_{i}(9)$ and appoint condensation pressure $p_{\text {sat }(\theta s i, \min )}(10)$,so that the relative humidity at the surface does not exceed the value of 0.8 . The next step is calculation of minimum allowable temperature of the inner surface of the partition minimum allowable temperature of the inner surface of the partition $\theta_{s i \text { min }}$ $(11,12)$, below which mold begins to grow and determination of factor $f_{R s i}$. The month in which the factor is highest $\left(f_{R s i, k r y t}\right)$ is called critical.

$$
\begin{aligned}
& p_{\text {sat }}=610,5 \cdot e^{\frac{17,26 \cdot \theta_{e}}{237,5+\theta_{e}}} \text { dla } \theta_{e} \geq 0{ }^{\circ} \mathrm{C} \\
& p_{\text {sat }}=610,5 \cdot e^{\frac{21,875 \cdot \theta_{e}}{265,5+\theta_{e}}} \text { dla } \theta_{e}<0^{\circ} \mathrm{C} \\
& p_{e}=\phi_{e} \cdot p_{\text {sat }} \\
& p_{i}=p_{e}+1,1 \cdot \Delta p \\
& p_{s t a\left(\theta_{s i, \min }\right)}=\frac{p_{i}}{0,8} \\
& \theta_{s i, \min }=\frac{237,5 \ln \left(\frac{p_{\text {sat }}}{610,5}\right)}{17,269-\ln \left(\frac{p_{\text {sat }}}{610,5}\right)} \text { dla } p_{\text {sat }(\theta s i, \text { min })} \geq 610,5 \mathrm{~Pa}
\end{aligned}
$$




$$
\theta_{s i, \min }=\frac{265,5 \ln \left(\frac{p_{\text {sat }}}{610,5}\right)}{21,875-\ln \left(\frac{p_{\text {sat }}}{610,5}\right)} \text { dla } p_{\text {sat }((s i, \text { min })}<610,5 \mathrm{~Pa}
$$

The factor $f_{\text {Rsi,kryt }}$ was specified for the city of Lublin based on weather data obtained from the website of the Ministry of Infrastructure and Development [12]. The values of the various stages of the calculations are summarized in Tab. 6.

Table 6. The results of calculations of the temperature coefficient $f_{\text {Rsi,kryt }}$

\begin{tabular}{lllllllllll}
\hline \multirow{2}{*}{ Month } & $\begin{array}{l}\theta_{e} \\
{\left[{ }^{\circ} \mathrm{C}\right]}\end{array}$ & $\begin{array}{l}\varphi_{e} \\
{[\%]}\end{array}$ & $\begin{array}{l}\theta_{i} \\
{\left[{ }^{\circ} \mathrm{C}\right]}\end{array}$ & $\begin{array}{l}\varphi_{i} \\
{[\%]}\end{array}$ & $\begin{array}{l}p_{e} \\
{[\mathrm{~Pa}]}\end{array}$ & $\begin{array}{l}\Delta p \\
{[\mathrm{~Pa}]}\end{array}$ & $\begin{array}{l}p_{i} \\
{[\mathrm{~Pa}]}\end{array}$ & $\begin{array}{l}p_{\text {sat }(\theta s i, m i n)}[\mathrm{Pa}] \\
\theta_{\text {si, min }}\end{array}$ & $f_{\text {Rsi,min }}$ & $f_{\text {Rsi,kryt }}$ \\
\hline January & -2.6 & 87 & 20.0 & 61 & 428 & 915 & 1435 & 1794 & 15.8 & 0.814 \\
\hline February & -1.9 & 86 & 20.0 & 61 & 449 & 887 & 1424 & 1780 & 15.7 & 0.803 \\
\hline March & 3.2 & 81 & 20.0 & 59 & 624 & 680 & 1373 & 1716 & 15.1 & 0.709 \\
\hline April & 9.2 & 73 & 20.0 & 57 & 844 & 437 & 1326 & 1657 & 14.6 & 0.496 \\
\hline May & 14.4 & 73 & 20.0 & 62 & 1205 & 227 & 1454 & 1818 & 16.0 & 0.287 \\
\hline June & 16.2 & 78 & 20.0 & 68 & 1430 & 154 & 1599 & 1999 & 17.5 & 0.343 \\
\hline July & 16.9 & 78 & 20.0 & 70 & 1495 & 126 & 1633 & 2041 & 17.8 & 0.301 \\
\hline August & 16.9 & 77 & 20.0 & 70 & 1487 & 126 & 1625 & 2032 & 17.8 & 0.277 \\
\hline September & 12.8 & 83 & 20.0 & 66 & 1221 & 292 & 1542 & 1927 & 16.9 & 0.572 \\
\hline October & 8.5 & 84 & 20.0 & 62 & 928 & 466 & 1440 & 1800 & 15.8 & 0.639 \\
\hline November & 1.3 & 89 & 20.0 & 61 & 598 & 757 & 1431 & 1789 & 15.8 & 0.773 \\
\hline December & -2.1 & 88 & 20.0 & 62 & 453 & 895 & 1438 & 1797 & 15.8 & 0.811 \\
\hline
\end{tabular}

Surface condensation does not occur if the factor $f_{\text {Rsi,kryt }}$ is less than the value of factor for the wall $-f_{R s i}$. In case of a barrier consisting of heterogeneous heat layers, the coefficient is calculated as the following formula (13).

$$
f_{R s i}=1-\frac{R_{s i, \min }}{R_{T, \min }}
$$

$R_{T, \min }$ is the lowest thermal resistance for the section of a building component. In the analysed models it is the value of resistance for cross sections passing through the frame, marked with the letter B. In the first case of wall obtained result is $f_{R s i}=0,951$, in the second $-f_{R s i}=0,940$. Both of these values are lower than $f_{R s i, k r y t}=0,814$, what means that in the analysed models of external walls the risk of mold growth is not occur.

\section{The determination of the distribution of pressure and temperature in the wall}

Analysis of temperature distribution in the partition is not required by law, so the calculation method is not from a norm, but the literature [13]. The calculation starts from determining the density of heat flow q of the partition, which separates the room with a temperature $t_{i}$ from external air with a temperature $t_{e}$, which is given by the formula (14).On individual layers of the partition heat flow causes a drop in temperature equal the product of the flux 
density and the values of following thermal resistances. This is why the temperatures at the interface between successive layers are calculated from the formula (15).

$$
\begin{aligned}
& q=U\left(t_{i}-t_{e}\right)=\frac{t_{i}-t_{e}}{R_{T}} \\
& v_{j}=t_{i}-q\left(R_{s i}+R_{1}+R_{2}+\ldots+R_{j}\right)=t_{i}-U\left(R_{s i}+R_{1}+R_{2}+\ldots+R_{j}\right)\left(t_{i}-t_{e}\right)
\end{aligned}
$$

The calculation of pressure distribution of water vapour in partition allows determining the risk of the occurrence of interstitial condensation. For this purpose, the barrier have to be divided into layers, for which should be determined the thermal resistance and an diffusion-equivalent air-layer $s_{d}$. Each of the layers must meet requirement $R \leq 0,25$ $\left(\mathrm{m}^{2} \cdot \mathrm{K}\right) / \mathrm{W}$. If the resistance is greater, than the layer should be divided into a plurality of identical, smaller layers that fulfil the condition. The next step is to calculate the temperatures at the contacts of the layers and determine the saturated vapour pressure $p_{\text {sat }}$. The actual distribution of water vapour pressure compared with the distribution of the saturated vapour pressure. On the basis of curves of the two values is possible to determine by the risk of the occurrence of interstitial condensation. The risk does not occur when on any contact surface the value of water vapour pressure does not exceed the value of the saturated vapour. When on one or more of the contact surfaces there is a possibility of condensation, it is necessary to prepare a balance the moisture, because when condensate can evaporate, a risk of degradation of the materials under the moisture should be checked. If the condensate cannot evaporate during the summer months, the wall have to be redesigned. The described algorithm is based on the Glaser method, who although a number of simplifications for example does not account for variability in material properties depending on their moisture and it is performed only for a period of one year, in accordance with EN ISO 13778 [11] shall be accepted for use.

These activities were carried out for both variants of the outer wall selected on the basis of the calculation of the coefficient $U$. In addition, for the second variant, which is the wall insulated with hemp wool, two cases were considered: a first where insulating layer is disposed on the outside and a second with a layer of insulation on the inside.

Charts for the coldest months (January and December), that pose the greatest risk of occurrence of condensation, for wall made with a mixture laid and compacted in formwork shown in Fig. 8 to 9. Because the possibility of condensation is shown on the contact layer of composite and exterior plaster, for this section of the wall in Tab. 7, a balance of flow condensation $g_{c}$ and the quantity of accumulated condensate $M_{a}$ is prepared.

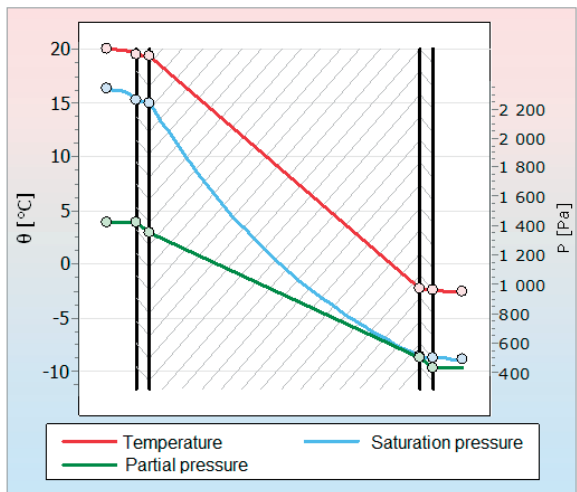

Fig. 8. The graph for January

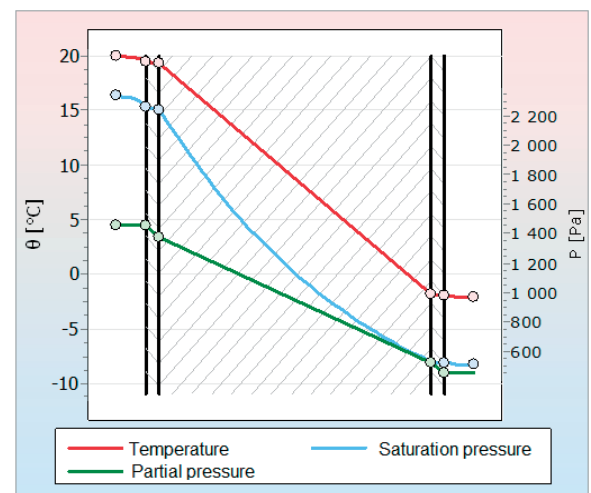

Fig. 9. The graph for December 
Table 7. The monthly flows of the condensation and accumulation inside the partition

\begin{tabular}{lllll}
\hline Month & I & II & III-XI & XII \\
\hline$g_{c}\left[\mathrm{~kg} / \mathrm{m}^{2}\right]$ & -0.0017 & -0.0027 & 0.0000 & 0.0043 \\
\hline$M_{a}\left[\mathrm{~kg} / \mathrm{m}^{2}\right]$ & 0.0027 & 0.0000 & 0.0000 & 0.0043 \\
\hline
\end{tabular}

The highest summary condensation flux $g_{c}$ takes place in December and it is equal $0.0043 \mathrm{~kg} / \mathrm{m}^{2}$. The maximum quantity of water vapour condensation, in amount $0.0043 \mathrm{~kg} / \mathrm{m}^{2}$ is also achieved in this month. The condensation occurs from December to February. From the month of March, liquefied condensate evaporates completely.

Analogous calculations and graphs (Fig. $10 \div 11$ ) were prepared for a wall made of composite sprayed onto lost formwork and insulated by hemp wool on the outside of the wall, but in this case, no condensation occurs.

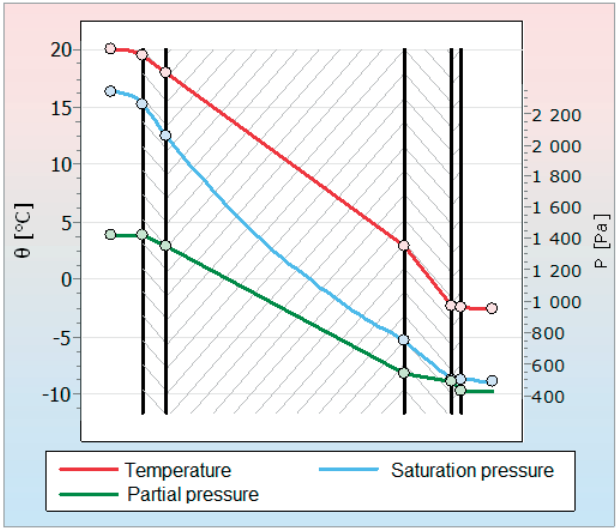

Fig. 10. The graph for January

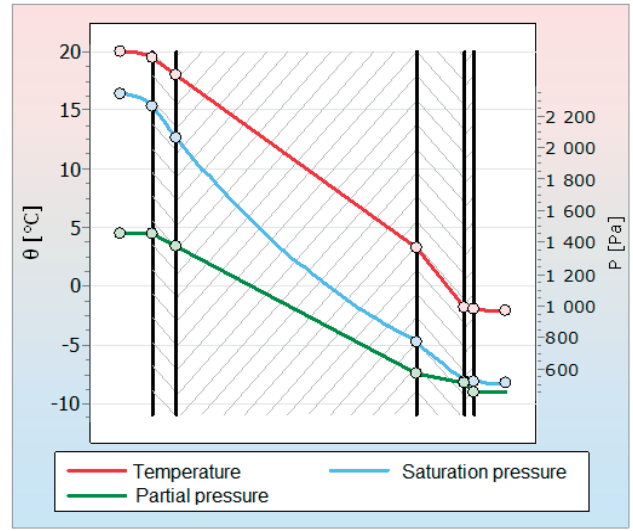

Fig. 11. The graph for December

The graphs for a wall with insulation placed on the inside are shown in Fig. $12 \div 13$. Also, in this case, condensation does not occur.

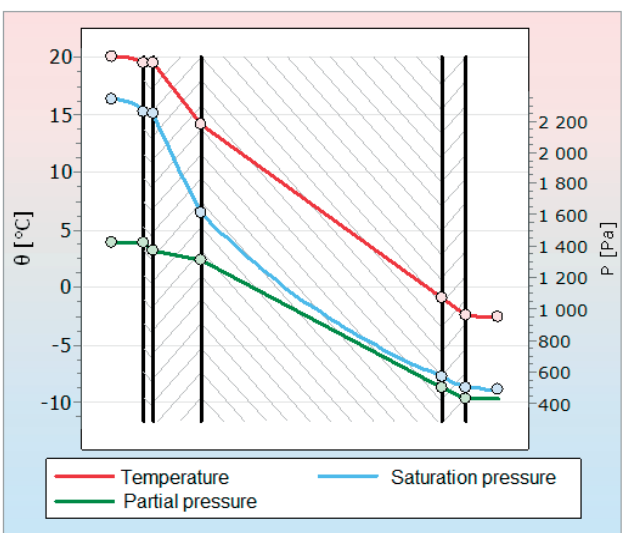

Fig. 12. The graph for January

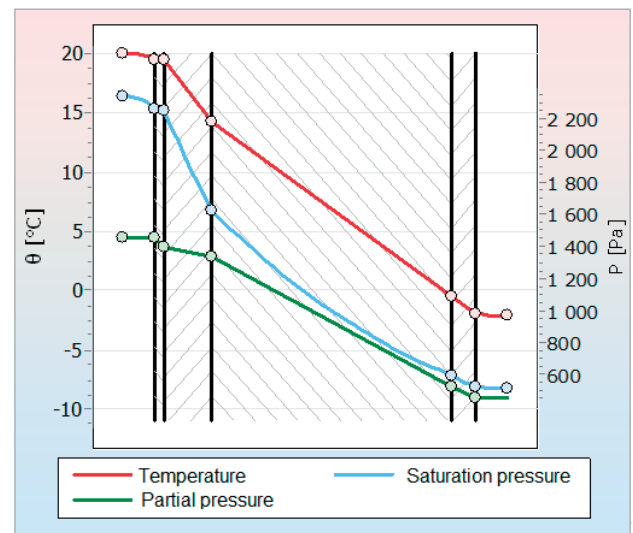

Fig. 13. The graph for December

The graphs shown in Fig. $8 \div 13$ was prepared by using the Purmo OZC program. 


\section{Summary}

Studies showed that the outer walls made of hemp-lime composite meet the criteria in terms of heat transfer coefficient $U$ and the risk of mold. In case of the wall insulated by hemp wool, condensation does not occur and condensate, which can occur between the layers of walls made of composite laid in shuttering, is able to evaporate. This means that the requirements dictated by law and relating to the thermal and humidity properties are met. This also proves that natural building materials successfully meet the current demands for building partitions. Therefore, instead of inventing and investing in new solutions based on the use of synthetic materials, whose task is to be impervious to moisture, the focus should be on natural solutions that under appropriate conditions, allow drying of the accumulated moisture. This will affect both the comfort of buildings and the quality of the environment, where they are located.

\section{References}

1. Stanwix W., Sparrow A., The Hempcrete Book - Designing and building with hemp-lime. England, Green Books, 2014.

2. www.japanhemp.org/en/miasahouse.htm

3. Allin S., Building with Hemp. Ireland, Seed Press, 2012.

4. Bevan A., Woolley T., Hemp lime construction - A guide to building with hemp lime composites, England, BRE Press, 2008.

5. Evrard A., Sorption behaviour of Lime-Hemp Concrete and its relations to indoor comfort and energy demand, The 23rd Conference on Passive and Low Energy Architecture, Geneva, 2006.

6. Firląg S., Szczelność powietrzna budynków pasywnych i energooszczędnych - wyniki badań. Czasopismo Techniczne Budownictwo, 2-B (2012) 107-113.

7. Booklet: The Thermal Performance of Tradical Hemcrete.

8. EN ISO 6946:2007: Building components and building elements - Thermal resistance and thermal transmittance - Calculation method.

9. Rozporządzenie Ministra Infrastruktury z dnia 12 kwietnia 2002 r. w sprawie warunków technicznych, jakim powinny odpowiadać budynki i ich usytuowanie (Dz. U. Nr 75, poz. 690, ze zmianami z dnia 5 lipca 2013 r.).

10. Treść Programu priorytetowego Narodowego Funduszu Ochrony Środowiska i Gospodarki Wodnej „Poprawa efektywności energetycznej”.

11. ISO 13788:2012 „Hygrothermal performance of building components and building elements. Internal surface temperature to avoid critical surface humidity and interstitial condensation. Calculation methods", International Organization for Standardization, Switzerland.

12. www.mir.gov.pl/strony/zadania/budownictwo/dane-do-swiadectw-charakterystykienergetycznej-budynkow

13. Dylla A., Praktyczna fizyka cieplna budowli. Bydgoszcz, Wydawnictwa uczelniane UTP, 2009. 
